\title{
Synthesis of (S)-(+)-2-Methyl-4-octanol: Male-Specific Compound Released by Sugarcane Weevil Sphenophorus levis (Coleoptera: Curculionidae)
}

\author{
Paulo H. G. Zarbin*, Jefferson L. Princival, Alcindo A. dos Santos and Alfredo R. M. de Oliveira \\ Departamento de Química, Universidade Federal do Paraná, CP 19081, 81531-990 Curitiba - PR, Brazil
}

\begin{abstract}
O composto $(S)$-2-metil-4-octanol (1) é produzido especificamente pelos machos da broca da cana-de-açúcar Sphenophorus levis, e sua atividade biológica está aparentemente associada ao comportamento de agregação da espécie. Desenvolveu-se neste trabalho uma nova metodologia sintética para a preparação deste composto, utilizando-se o $D$-manitol (2) como material de partida, tendo-se o $(R)$-gliceraldeído acetonídeo (4) como intermediário chave. Através de análises cromatográficas de um acetil derivado do produto final, empregando-se colunas quirais, estabeleceuse um excesso enantiomérico de $99,5 \%$. O composto (1) já foi previamente identificado como componente do feromônio de agregação de uma grande variedade de espécies de curculionídeos.
\end{abstract}

$(S)$-2-Methyl-4-octanol (1) is a male-specific compound released by the sugarcane weevil Sphenophorus levis, being its biological activity associated with the aggregation behaviour of the species. Continuing our studies on the chemical ecology of this species, this work describes an expeditious synthesis of alcohol (1), starting from the easily available $D$-mannitol (2), in a route that employ the known $(R)$-glyceraldehyde acetonide (4) as key intermediate. GC analysis of an acetyl derivative of the final product, using a chiral stationary phase column, revealed an enantiomeric excess of $99.5 \%$. Compound (1) has been identified as component of the male-produced aggregation pheromone in several curculionid species.

Keywords: Sphenophorus levis, aggregation pheromone, 2-methyl-4-octanol, synthesis, sugarcane weevil, curculionidae

\section{Introduction}

The genus Sphenophorus is commonly found in the South America having up to fourteen species described in Brazil. Sphenophorus levis (Coleoptera: Curculionidae) was first identified as a new species in 1978 and it is an important pest against sugarcane. ${ }^{1}$ Due to its behaviour in the larval stage, synthetic insecticides have been unsuccessfully used to control this weevil. During this period, as occur with other species of this family, S. levis digs tunnels on sugarcane stalks, destroys tissues, and weakens the plant. ${ }^{2}$ Because of that, attractive semiochemicals can be employed as an extremely useful tools in integrated pest management.

We have recently identified the alcohol (S)-2-methyl4-octanol (1) as a male-specific compound produced by $S$. levis. ${ }^{3}$ Preliminary indoor bioassays employing the racemic mixture suggested that this compound elicit aggregation behavior among both males and females of the species. ${ }^{3,4}$

*e-mail: pzarbin@quimica.ufpr.br
The same compound has been identified as a component of the male-produced aggregation pheromone in several curculionid species. ${ }^{5-7}$

In order to establish the importance of the stereochemistry on the biological activity of this compound, we have developed an alternative synthesis of $(S)$-(1), starting from $D$-mannitol (2). The natural isomer and the previously synthesized racemic compound ${ }^{3}$ will be employed in field experiments, and the results will appear elsewhere.

\section{Experimental}

Gas chromatography analyses were performed on a Varian 3800 GC equipped with FID, electronic pressure control, and operated in split mode. The following capillary column was used: VA-5 ( $30 \mathrm{~m} \times 0.25 \mathrm{~mm}$ x $0.25 \mathrm{~mm}$ ), oven temperature was held at $50{ }^{\circ} \mathrm{C}$ for $3 \mathrm{~min}$, programmed at $7{ }^{\circ} \mathrm{C} \min ^{-1}$ to $230{ }^{\circ} \mathrm{C}$, and held at this temperature for

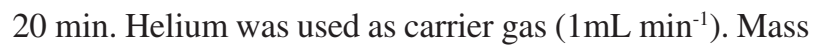
spectra were recorded on a Varian Saturn 2000 GC/MS/MS ion trap detector using the same type VA-5 capillary column 
under the same condition described above. The equipment was operated in the electron impact (EI) ionization mode $(70 \mathrm{eV})$ and in the chemical ionization $(\mathrm{CI})$ mode $\left(\mathrm{CH}_{3} \mathrm{CN}\right)$. Chiral separations were obtained on a cyclodextrin-based capillary column [Cyclosil-B, w/w $30 \mathrm{~m}, 0.25 \mathrm{~mm}$ i.d, $0.25 \mu \mathrm{m}$; J\&W Scientific] using helium as carrier gas $(275.8 \mathrm{KPa})$ at $60{ }^{\circ} \mathrm{C}$. High-Resolution-GC-Mass-Spectra (HR-GC-MS) was carried out on a HP6890(GC)/VG7070(MS), operated in the electron impact (EI) ionization mode $(70 \mathrm{eV})$. The following capillary column was used: BPX5 (30 m x $0.25 \mathrm{~mm} \times 0.25 \mu \mathrm{m})$, oven temperature was held at $80{ }^{\circ} \mathrm{C}$ for $3 \mathrm{~min}$, programmed at $5^{\circ} \mathrm{C} \mathrm{min}^{-1}$ to $300^{\circ} \mathrm{C}$, held at this temperature for $10 \mathrm{~min}$. Helium was used as carrier gas $\left(1 \mathrm{~mL} \mathrm{~min}{ }^{-1}\right)$. The IR spectra refer to films and were measured on a Bomem M-102 spectrometer. The ${ }^{1} \mathrm{H}-\mathrm{NMR}$ spectra were recorded with TMS as an internal standard at 400 and $200 \mathrm{MHz}$ on a Bruker ARX-400 and ARX-200 spectrometer, respectively. The ${ }^{13} \mathrm{C}-\mathrm{NMR}$ spectra were recorded with TMS as an internal standard at 100 and $50 \mathrm{MHz}$ on a Bruker ARX-400 and ARX-200 spectrometer, respectively. Optical rotations were measured on a Bellinghan + Stanley Ltd Model D polarimeter. All reagents and solvents used in the syntheses were of highest commercially available standard. Chromatographic purifications were carried out on silica gel 60, Merck, 230-400 mesh.

1,2:5,6-Diisopropylidene-D-mannitol (3). D-mannitol $(25.00 \mathrm{~g}, 137.4 \mathrm{mmol})$ was added to a solution of freshly distilled 1,2-dimethoxyethane $(60.0 \mathrm{~mL}, 580 \mathrm{mmol})$ in 2,2-dimethoxypropane $(40.0 \mathrm{~mL}, 326 \mathrm{mmol})$, and the mixture was stirred for $15 \mathrm{~min} . \mathrm{SnCl}_{2}(0.025 \mathrm{~g}, 0.13 \mathrm{mmol})$ was added and the stirred slurry was heated to reflux for $1.5 \mathrm{~h}$. The solution was cooled below reflux and pyridine $(50 \mu \mathrm{L})$ was added. The solvent was removed on a rotary evaporator, and $45 \mathrm{~g}$ of crude solid product was obtained. Recrystalization from $\mathrm{CH}_{2} \mathrm{Cl}_{2}$ afforded $19.8 \mathrm{~g}$ of pure product 3 , in $55 \%$ yield. $[\alpha]_{\mathrm{D}}{ }^{23}+1.8^{\circ}\left(c 1.5, \mathrm{CH}_{3} \mathrm{OH}\right)$, $\mathrm{Lit}^{8}$ : $[\alpha]_{\mathrm{D}}^{23}+1.9^{\circ}\left(c 2.0, \mathrm{CH}_{3} \mathrm{OH}\right)$; IR $v_{\max .} / \mathrm{cm}^{-1}: 3407,3273,2992$, 1384, 1368; ${ }^{1} \mathrm{H}-\mathrm{NMR}\left(200 \mathrm{MHz}, \mathrm{CDCl}_{3}\right) \delta 1.29(\mathrm{~s}, 6 \mathrm{H})$, 1.35 (s, 6H), $2.64\left(\mathrm{~d},{ }^{3} J 6.6 \mathrm{~Hz}, 2 \mathrm{H}\right), 3.67\left(\mathrm{t},{ }^{3} J 6.6 \mathrm{~Hz}, 2 \mathrm{H}\right)$, 3.85-3.96 (m, 2H), 4.01-4.16 (m, 4H); ${ }^{13} \mathrm{C}-\mathrm{NMR}(50 \mathrm{MHz}$, $\left.\mathrm{CDCl}_{3}\right) \delta 25.2,26.7,66.7,71.2,76.2,109.4$.

\section{2,3-O-Isopropylidene-D-glyceraldehyde (4). An} emulsion of compound 3 (19.8 g, $75.6 \mathrm{mmol}$ ) in $\mathrm{CH}_{2} \mathrm{Cl}_{2}$ $(350 \mathrm{~mL})$, was kept under magnetic stirring and heated until total dissolution of the solid. The system was cooled to room temperature. Celite $(5.0 \mathrm{~g})$ was added and the suspension was filtered, collecting the filtrate in a reaction flask. A saturated solution of $\mathrm{NaHCO}_{3}(10 \mathrm{~mL})$ was added, followed by $\mathrm{NaIO}_{4}(35.0 \mathrm{~g}, 163.5 \mathrm{mmol})$. The reaction was kept under magnetic stirring, and the internal temperature was kept lower than $35^{\circ} \mathrm{C}$. After $2 \mathrm{~h}, \mathrm{Na}_{2} \mathrm{SO}_{4}(13 \mathrm{~g})$ was added, and the stirring was kept for additional $20 \mathrm{~min}$. The mixture was filtered, and the residue was washed several times with $\mathrm{CH}_{2} \mathrm{Cl}_{2}$. The solvent was removed by distillation, and the residue was distilled under reduced pressure (30 $\mathrm{mmHg}$ ), affording $14.5 \mathrm{~g}$ of the crude aldehyde 4 . Another distillation was carried out, collecting the material between $67-72^{\circ} \mathrm{C}$, yielding $12.0 \mathrm{~g}(61 \%)$ of pure aldehyde $4 .[\alpha]_{\mathrm{D}}+$ $72^{\circ}$ (c 1.5 benzene), Lit $^{8,9}[\alpha]_{\mathrm{D}}:+70-80^{\circ}$ (c 1.5 benzene); IR $v_{\text {max. }} / \mathrm{cm}^{-1}: 2990,2940,2825,2890,1738,1215,1073 ;{ }^{1} \mathrm{H}-$ NMR $\left(400 \mathrm{MHz}-\mathrm{CDCl}_{3}\right) \delta 1.40(\mathrm{~s}, 3 \mathrm{H}), 1.47(\mathrm{~s}, 3 \mathrm{H}), 4.12$ (m, 2H), $4.36(\mathrm{~m}, 1 \mathrm{H}), 9.52\left(\mathrm{~d},{ }^{3} J 1.8 \mathrm{~Hz}, 1 \mathrm{H}\right)$.

(4S)-4-But-1-enyl-2,2-dimethyl-1,3-dioxolane (5). A suspension of propyltriphenylphosphonium bromide, ${ }^{10}$ $(7.40 \mathrm{~g}, 19.2 \mathrm{mmol})$ in THF $(150 \mathrm{~mL})$ was stirred at room temperature for $20 \mathrm{~min}$, and then cooled to $-78{ }^{\circ} \mathrm{C}$. $n \mathrm{BuLi}$ (8.70 mL, $2.35 \mathrm{~mol} \mathrm{~L}^{-1}$ in hexane) was added slowly (solution becomes orange). The solution was gradually warmed to room temperature and kept under stirring for 30 min. After being cooled again to $-78^{\circ} \mathrm{C}$, the freshly distilled aldehyde 4 ( $1.95 \mathrm{~g}, 15.0 \mathrm{mmol})$ in THF (20 mL) was slowly added to the solution. The cooling bath was removed (solution became white with the increase of the temperature) and the reaction was stirred overnight. Celite (1.0 g) was added, and the resulting suspension was stirred for $15 \mathrm{~min}$ and filtered. The residue was washed with ethyl ether ( $3 \times 15 \mathrm{~mL})$, and the organic layer was concentrated in vacuo. The crude product was purified by chromatography over silica gel, using a mixture of hexane/ethyl ether $(5: 1 \mathrm{v} / \mathrm{v})$, affording $2.06 \mathrm{~g}$ of pure $5(88 \%) .[\alpha]_{\mathrm{D}}{ }^{23}$ : $+21.0^{\circ},(Z)$-isomer $\left(c\right.$ 2.5, $\left.\mathrm{CHCl}_{3}\right), \mathrm{Lit}^{10}:[\alpha]_{\mathrm{D}}{ }^{23}:+21.8^{\circ}$ (c 2.8, $\mathrm{CHCl}_{3}$ ); IR $v_{\text {max. }} / \mathrm{cm}^{-1}: 3026,2990,2985,1655,1214$, $1058 ;{ }^{1} \mathrm{H}-\mathrm{NMR}\left(200 \mathrm{MHz}, \mathrm{CDCl}_{3}\right) \delta 0.92\left(\mathrm{t},{ }^{3} \mathrm{~J} 7.6 \mathrm{~Hz}, 3 \mathrm{H}\right)$, $1.32(\mathrm{~s}, 3 \mathrm{H}), 1.35$ (s, 3H), 1.89-2.22 (m, 2H), 3.44 (t, ${ }^{3} J 8.0$ $\mathrm{Hz}, 1 \mathrm{H}), 3.99$ (dd, ${ }^{3} J 8.0$ and $\left.6.0 \mathrm{~Hz}, 1 \mathrm{H}\right), 4.72-4.84(\mathrm{~m}$, 1H), 5.30 (ddt, ${ }^{3} J 10.8,8.6$, and $3.2 \mathrm{~Hz}, 1 \mathrm{H}$ ), 5.57 (dtd, ${ }^{3} J$ 10.8, 7.4, and $1.0 \mathrm{~Hz}, 1 \mathrm{H}) ;{ }^{13} \mathrm{C} \mathrm{NMR}\left(50 \mathrm{MHz}, \mathrm{CDCl}_{3}\right) \delta$ 14.32, 21.06, 25.96, 26.75, 69.48, 71.90, 108.98, 126.49, 136.66 .

(4S)-4-Butyl-2,2-dimethyl-1,3-dioxolane (6). A solution of $5(3.35 \mathrm{~g}, 21.5 \mathrm{mmol})$ in $n$-hexane $(26.0 \mathrm{~mL})$ was hydrogenated in a $\operatorname{Parr}^{\circledR}$ apparatus at $206.8 \mathrm{Kpa}$ for 12 hours with Lindlar catalyst (100 mg). After filtration and concentration, the residue was purified by chromatography over silica gel, using a mixture of hexane/ethyl ether (7:1 $\mathrm{v} / \mathrm{v})$, affording $2.75 \mathrm{~g}$ of pure $6(81 \%) .[\alpha]_{\mathrm{D}}^{23}:+20.1^{\circ}$ (c 1.45, $\left.\mathrm{CHCl}_{3}\right) ;{ }^{1} \mathrm{H}-\mathrm{NMR}\left(400 \mathrm{MHz}, \mathrm{CDCl}_{3}\right) \delta 0.91\left(\mathrm{t},{ }^{3} \mathrm{~J}\right.$ $7.0 \mathrm{~Hz}, 3 \mathrm{H}), 1.14-1.59$ (m, 5H), 1.37 (s, 3H), 1.42 (s, 3H), 1.60-1.71 (m, 1H), $3.50\left(\mathrm{t},{ }^{3} J 7.2 \mathrm{~Hz}, 1 \mathrm{H}\right), 4.01-4.11(\mathrm{~m}$, $2 \mathrm{H}) ;{ }^{13} \mathrm{C} \mathrm{NMR}\left(100 \mathrm{MHz}, \mathrm{CDCl}_{3}\right) \delta 14.04,22.75,25.77$, 26.96, 27.94, 33.30, 69.55, 76.17, 108.56. 
(2S)-1,2-Hexanediol (7). Acidic Dowex ${ }^{\circledR}$ W50 (9.8 g) was added to a stirred solution of $6(6.75 \mathrm{~g}, 42.7 \mathrm{mmol})$ in $\mathrm{H}_{2} \mathrm{O}(170 \mathrm{~mL})$, and the reaction was kept at $60^{\circ} \mathrm{C}$ overnight. The mixture was cooled and extracted with ethyl acetate $(3 \times 20 \mathrm{~mL})$. The organic layer was concentrated in vacuo, and the residue was subjected to column chromatography over silica gel, using a mixture of ethyl acetate/hexane $(3: 1 \mathrm{v} / \mathrm{v})$. Diol 7 was obtained pure in $79 \%$ yield $(3.97 \mathrm{~g})$. $\left.[\alpha]_{\mathrm{D}}^{23}:+2.0^{\circ}(c) 3.38, \mathrm{CHCl}_{3}\right)$; IR $v_{\text {max }} / \mathrm{cm}^{-1}: 3338,2932$, 2861, 1466, 1062; ${ }^{1} \mathrm{H}-\mathrm{NMR}\left(400 \mathrm{MHz}, \mathrm{CDCl}_{3}\right) \delta 0.91(\mathrm{t}$, $\left.{ }^{3} J 7.1 \mathrm{~Hz}, 3 \mathrm{H}\right), 1.25-1.50(\mathrm{~m}, 6 \mathrm{H}), 2.85(\mathrm{bs}, 2 \mathrm{H}), 3.42\left(\mathrm{dd},{ }^{3} \mathrm{~J}\right.$ 11.2 and $7.7 \mathrm{~Hz}, 1 \mathrm{H}), 3.62-3.73(\mathrm{~m}, 2 \mathrm{H}) ;{ }^{13} \mathrm{C}-\mathrm{NMR}(50$ $\left.\mathrm{MHz}, \mathrm{CDCl}_{3}\right) \delta 14.01,22.75,27.79,32.80,66.76,72.40$; GC-EIMS $m / z, 117\left(\mathrm{M}^{+}-1,2 \%\right) 101$ (14), 83 (100), 69 (77), 55 (08).

(4S)-2-Methyl-4-octanol (1). Diol 7 (0.630g, 5.35 $\mathrm{mmol})$ was dissolved in pyridine $(14 \mathrm{~mL})$ and cooled in an ice bath $\left(0{ }^{\circ} \mathrm{C}\right) . p$-Toluenesulfonyl chloride $(1.02 \mathrm{~g}$, $5.40 \mathrm{mmol}$ ) was added in small portions with constant stirring. The reaction was completed in $10 \mathrm{~h}$. Ethyl ether $(30 \mathrm{~mL})$ and water $(15 \mathrm{~mL})$ were added and the organic layer was washed several times with sat. $\mathrm{CuSO}_{4}$, and then dried with $\mathrm{MgSO}_{4}$. The solvent was removed under reduced pressure and the crude tosylate was column chromatographed, hexane/ethyl acetate $(1: 1 \mathrm{v} / \mathrm{v})$, on a silica gel column yielding $0.91 \mathrm{~g}$ of the mono tosylate $8(60 \%)$, which was used directly in the next step. To a stirred solution of $8(0.40 \mathrm{~g}, 1.43 \mathrm{mmol})$ in dry THF $(5 \mathrm{~mL})$ cooling below $40{ }^{\circ} \mathrm{C}$, was added $\mathrm{CuI}(0.270 \mathrm{~g}, 1.43 \mathrm{mmol})$ followed by dropwise addition of $s e c-\operatorname{PrMgBr}$ [a solution prepared from 2-bromopropane $(1.27 \mathrm{~mL}, 14 \mathrm{mmol})$ and $\mathrm{Mg}^{\circ}(0.34 \mathrm{~g}$, $14 \mathrm{mmol})$ in THF ( $8.0 \mathrm{~mL})$ ]. After addition was completed, the mixture turned dark. The mixture was allowed to warm to room temperature, and the stirring was continued for 1 h. The reaction was quenched by addition of sat. $\mathrm{NH}_{4} \mathrm{Cl}(8$ $\mathrm{mL})$. The aqueous layer was extracted with hexane:ethyl ether, $1: 1 \mathrm{v} / \mathrm{v},(3 \times 20 \mathrm{~mL})$, and the organic layer was dried over magnesium sulfate and concentrated carefully under a flux of argon. The product was purified by flash chromatography over silica gel using a mixture of hexane/ ethyl ether $(8: 1 \mathrm{v} / \mathrm{v})$, yielding compound $\mathbf{1}$ as a colorless oil $(0.16 \mathrm{~g}, 78 \%) .[\alpha]_{\mathrm{D}}^{23}:+10.2^{\circ}\left(c 2.3, \mathrm{CHCl}_{3}\right)$; IR $v_{\text {max. }} / \mathrm{cm}^{-1}$. 3346, 2956, 2928, 2870, 1466, 1026; ${ }^{1} \mathrm{H}-\mathrm{NMR}(400 \mathrm{MHz}$, $\left.\mathrm{CDCl}_{3}\right) \delta 0.90\left(\mathrm{~d},{ }^{3} J 6.6 \mathrm{~Hz}, 3 \mathrm{H}\right), 0.91\left(\mathrm{t},{ }^{3} J 7.0 \mathrm{~Hz}, 3 \mathrm{H}\right)$, $0.92\left(\mathrm{~d},{ }^{3} \mathrm{~J} 6.6 \mathrm{~Hz}, 3 \mathrm{H}\right), 1.19-1.48(\mathrm{~m}, 8 \mathrm{H}), 1.70(\mathrm{bs}, 1 \mathrm{H})$, 1.71-1.81 (m, 1H), 3.64-3.72 (m, 1H); ${ }^{13} \mathrm{C}-\mathrm{NMR}(100 \mathrm{MHz}$, $\left.\mathrm{CDCl}_{3}\right) \delta 14.50,22.46,23.17,23.91,25.03,28.22,38.19$, 47.22, 70.40; GC-EI-MS m/z 126(M+18, 1\%), 111(1), 87(38), 69(100), 57 (14), 43 (53); HR-GC-EI-MS ( $\left.\mathrm{M}^{+}-1\right)$ Found: 143.1445. Calcd.for $\mathrm{C}_{9} \mathrm{H}_{19} \mathrm{O}: 143.1435 \%$.

2-Methyloctanyl-4-acetate (1a). To a mixture of pyridine $(0.1 \mathrm{~mL})$ and compound $\mathbf{1}$ [racemic and $(S)$-isomer; $(0.01 \mathrm{~g}, 0.07 \mathrm{mmol})]$, acetic anhydride $(0.01 \mathrm{~mL}, 0.1 \mathrm{mmol})$ was added and the resulting mixture was stirred for $15 \mathrm{~min}$. The reaction was quenched by addition of sat. $\mathrm{NaHCO}_{3}$ solution $(0.2 \mathrm{~mL})$ followed by addition of ethyl ether $(0.5 \mathrm{~mL})$. The organic layer was dried over anhydrous magnesium sulfate, filtered, and the solution obtained was used directly as authentic sample of the racemic and $(S)$-acetates 1a. [(4S)-1a, $99.5 \%$ ee by chiral GC analyses, $\mathrm{R} t 62.66 \mathrm{~min}$; (4R/S)-1a, Rt 60.75 and $62.66 \mathrm{~min}]$.

\section{Results and Discussion}

The synthesis of $(S)$-2-methyl-4-octanol $\mathbf{1}$ is summarized in Scheme 1. The $(R)$-glyceraldehyde acetonide $\mathbf{4}$ was prepared in $33.5 \%$ yield from D-mannitol (2), by the known method, ${ }^{8,9}$ via an oxidative cleavage of the diol 3. The freshly distilled aldehyde $\mathbf{4}$ was subjected to the Wittig reaction with (triphenylphosphonium)propanide $\left(\mathrm{CH}_{3} \mathrm{CH}_{2} \mathrm{CH}=\mathrm{PPH}_{3}\right)^{11}$ to give compound $\mathbf{5}$ in $88 \%$ yield [it was observed that the (Z)-isomer was preferentially obtained, as indicated by ${ }^{1} \mathrm{H}-\mathrm{NMR}$ data]. Hydrogenation over $\mathrm{Pd} / \mathrm{C}$ furnished compound 6 ( $81 \%$ yield), which was hydrolyzed ${ }^{12}$ under acidic Dowex ${ }^{\circledR}$ resin (W50) yielding diol 7 in $79 \%$ yield. This diol $\mathbf{7}$ was converted into the mono tosylate $\mathbf{8}$ in $60 \%$ yield, by reaction with $\mathrm{TsCl}$ in pyridine, and then coupled with $s e c$-propyl magnesium bromide, using $\mathrm{CuI}$ as catalyst, ${ }^{3}$ affording the desired alcohol $\mathbf{1}$ in 78\% yield.

The enantiomeric purity of the final synthetic product could be estimated by chiral GC analisys of its respective acetyl derivative 1a (prepared by reaction of $(R / S)_{-}{ }^{3}$ and $(S)-\mathbf{1}$ with $\mathrm{Ac}_{2} \mathrm{O}$ in pyridine ${ }^{11}$, , since no resolution was possible for the alcohol 1 employing the Cyclosil- $\mathrm{B}^{\circledR}$ column. Racemic 1a was resolved to baseline, showing two peaks with retention times of 60.75 and 62.66 min. The $(S)$-1a isomer corresponded to the second peak, and the analysis indicated an e.e.> $99.5 \%$ (Figure 1).

Few examples of enantioselective synthesis of compound $\mathbf{1}$ have appeared in the literature. Mori and coworkers ${ }^{13}$ described the first synthesis of $(R)$ - and $(S)-\mathbf{1}$ in five steps and $11 \%$ overall yield, starting from $(R)$ - and $(S)$-leucine. Baraldi and co-workers ${ }^{14}$ published a synthetic route for both isomers of $\mathbf{1}$, employing a microbiological reduction of $\beta$-ketoesters as asymmetric source. $(R)-\mathbf{1}$ was prepared in five steps and $20 \%$ overall yield, while the $(S)$ enantiomer was synthesized in 6 steps and $14 \%$ overall yield. More recently, we developed a short synthesis of $(R)$ - and $(S)$-1 in $92 \%$ e.e, starting from $(R)$ - and $(S)$-2,2dimethyl-1,3-dioxolane-4-methanol. ${ }^{3}$ These synthetic compounds were successfully employed as authentic 


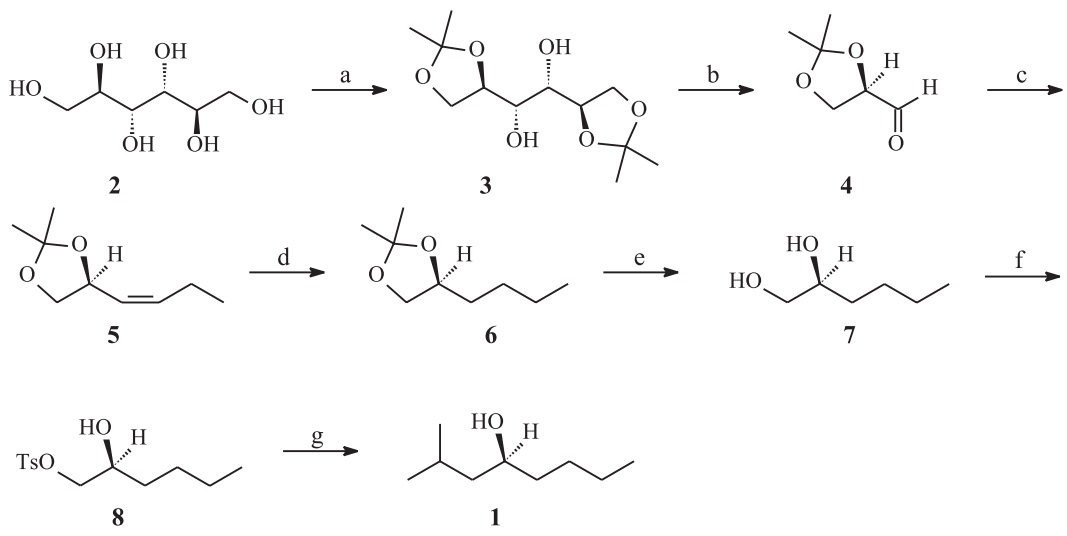

Scheme 1. Synthesis of (S)-(+)-2-methyl-4-octanol (1). Reagents: a) $\mathrm{SnCl}_{2}, 2,2-\mathrm{DMP}, 55 \%$; b) $\mathrm{NaIO}_{4}, \mathrm{NaHCO}_{3}, \mathrm{CH}_{2} \mathrm{Cl}_{2}, 61 \%$; c) $\mathrm{CH}_{3} \mathrm{CH}_{2} \mathrm{CH}_{2} \mathrm{PPh}_{3} \mathrm{Br}$, BuLi, THF, 88\%; d) $\mathrm{H}_{2}, \mathrm{Pd} / \mathrm{CaCO}_{3}$, hexane, $81 \%$; e) acidic Dowex ${ }^{\circledast}$ W50, $\mathrm{H}_{2} \mathrm{O}, 79 \%$; f) TsCl, Py, 60\%; g) $s-\mathrm{C}_{3} \mathrm{H}_{7} \mathrm{MgBr}, \mathrm{CuI}, \mathrm{THF}, 78 \%$.

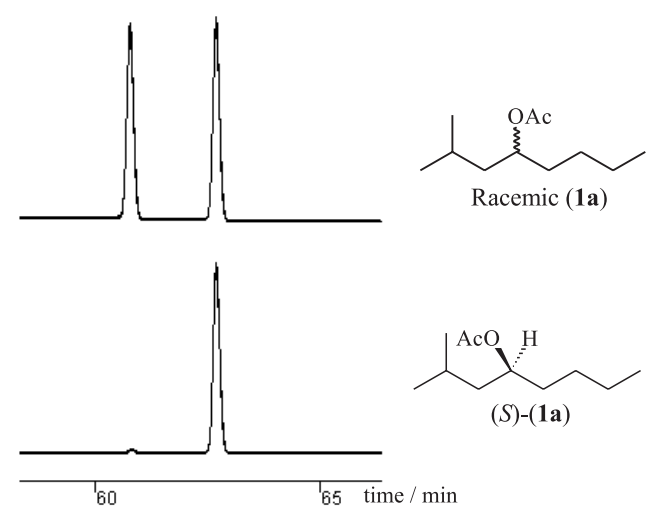

Figure 1. Resolution of $(R / S)$ - and $(S)$-2-methyloctanyl-4-acetate, (1a) on a Cyclosil-B ${ }^{\circledR}$ chiral column $(60.75$ and $62.66 \mathrm{~min})$. For conditions, see Experimental Section.

samples to establish the absolute configuration of the natural product released by males $S$. levis, ${ }^{3}$ but could not be used as attractants in field experiments due to the poor enantiomeric enhancement. We have now introduced a new approach to $(S)$-1, starting from the easily available $D$-mannitol 2, a route which uses the known $(R)$ glyceraldehyde acetonide $\mathbf{4}$ as key intermediate, over seven steps and $8.8 \%$ overall yield. The example given here shows that this natural isomer can be obtained via an operationally simple strategy.

\section{Acknowledgment}

We thank the IFS (Sweden), OPCW (Netherlands), $\mathrm{CNPq}$ and Fundação Araucária (Brazil) for financial support (grant to PHGZ). We are in debt with Prof. Dr. Antonio G. Ferreira (DQ-UFSCar) for running ${ }^{1} \mathrm{H}-\mathrm{NMR}$ and ${ }^{13} \mathrm{C}-\mathrm{NMR}$ of the synthetic compounds, and with Dr. Nicolas Heinzel (Institute of Organic Chemistry, University of Hamburg) for high resolution mass spectra analysis

\section{References}

1. Vanin, S.A.; A New Species of Sphenophorus Schoenher from Brazil (Coleoptera, Curculionidae, Rhynchophorinae), Departamento de Zoologia, Instituto de Biociências-USP, Ed. USP: São Paulo, 1988, p.9.

2. Cerda, H.; Fernandez, G.; Lopez, A.; Varga, J.; Fla. Entomol. 1999, 82, 103

3. Zarbin, P.H.G.; Arrigoni, E.D.B.; Reckziegel, A.; Moreira, J.A.; Baraldi, P.T.; Vieira, P.C.; J. Chem. Ecol. 2003, 29, 377.

4. Zarbin, P.H.G.; Arrigoni, E.D.B.; Moreira, J.A.; Baraldi, P.T.; Vieira, P.C.; Abstracts of the $1^{\text {st }}$ Encontro Brasileiro de Ecologia Química, Curitiba, Brazil, 1999.

5. Oehlschlager, A.C.; Prior, R.N.B.; Perez, A.L.; Gries, R.; Gries, G.; Pierce, H.D., Jr.; Laup, S.; J. Chem. Ecol. 1995, 21, 1619.

6. Ramirez-Lucas, P.; Malosse, C.; Ducrot, P.H.; Lettere, M.; Zagatti, P.; Bioorg. Med. Chem. 1996, 4, 323.

7. Giblin-Davis, R.M.; Gries, R.; Crespi, B.; Robertson, L.N.; Hara, A.H.; Gries, G.; O’Brien, C.W., Pierce Jr., H.D.; J. Chem. Ecol. 2000, 26, 2763.

8. Häfele, B.; Jäger, V.; Liebigs. Ann. Chem. 1987, 85.

9. Horton, D.; Thomson, J.B. J. Org. Chem. 1968, 33, 728; Mann, J.; Partlett, N.K.; Thomas, A.; J. Chem. Res. 1987, 369.

10. Francke, W.; Schröder, F.; Walter, F.; Sinnwell, V.; Baumann, H.; Kaib, M.; Liebigs Ann. 1995, 965.

11. Zarbin, P.H.G.; Reckziegel, A.; Plass, E.; Oliveira, A.R.M.; Simonelli, F.; Marques, F.A.; J. Braz. Chem. Soc. 2000, 11, 572.

12. Mulholland, G.K.; Nuc. Med. Biol. 1995, 22, 19.

13. Takenaka, M.; Takikawa, H.; Mori, K.; Liebigs Ann. 1996, 1963.

14. Baraldi, P.T.; Zarbin, P.H.G.; Vieira, P.C.; Correa, A.G.; Tetrahedron: Asymmetry 2002, 13, 621.

Received: July 2, 2003

Published on the web: April 2, 2004 